\title{
Composition and Molecular Identification of Bacterial Community in Seawater Desalination Plants
}

\section{Pilar Garcia-Jimenez ${ }^{1 *}$ (1), Marina Carrasco-Acosta1 ${ }^{1}$, Carlos Enrique Payá1, Irina Alemán López ${ }^{1}$, Juana Rosa Betancort Rodríguez ${ }^{2}$, José Alberto Herrera Melián ${ }^{3}$}

\footnotetext{
${ }^{1}$ Department of Biology, Universidad de Las Palmas de Gran Canaria, Campus de Tafira, Las Palmas, Spain

${ }^{2}$ Department of Water, Instituto Tecnológico de Canarias, Playa de Pozo Izquierdo, Las Palmas, Spain

${ }^{3}$ Department of Chemistry, Universidad de Las Palmas de Gran Canaria, Campus de Tafira, Las Palmas, Spain

Email: *pilar.garcia@ulpgc.es
}

How to cite this paper: Garcia-Jimenez, P., Carrasco-Acosta, M., Payá, C.E., López, I.A., Rodríguez, J.R.B. and Melián, J.A.H. (2019) Composition and Molecular Identification of Bacterial Community in Seawater Desalination Plants. Advances in Microbiology, 9, 863-876.

https://doi.org/10.4236/aim.2019.910053

Received: July 23, 2019

Accepted: October 18, 2019

Published: October 21, 2019

Copyright $\odot 2019$ by author(s) and Scientific Research Publishing Inc. This work is licensed under the Creative Commons Attribution International License (CC BY 4.0).

http://creativecommons.org/licenses/by/4.0/

(c) (i) Open Access

\begin{abstract}
Biofouling is an important problem for reverse osmosis (RO) membrane manufacturers. Bacteria are mainly involved in generating fouling and obturating RO membranes. Insights into biofilm bacteria composition could help prevent biofouling, reduce the cost of using RO-fouling membranes and guarantee safe water. Culture-dependent and independent techniques were then performed in order to identify bacteria associated with RO membranes. Bacteria cultures described the presence of six pure colonies, four of which were identified through API testing. Based on 16s rRNA gene analysis, a predominant bacterium was identified and annotated as Sphingomonas sp. The 16s rRNA gene clone library, on the other hand, showed that the bacterium, Pseudomonas marincola, accounted for nearly $30 \%$ of the clone library, while the rest of bacteria were chimeras (62\%) and non-representative species (3\%). In conclusion, culture-dependent and independent approaches showed that two dominant bacteria were commonly observed in RO desalination membranes.
\end{abstract}

\section{Keywords}

Biofouling, Bacteria, 16s rRNA, Reverse Osmosis Membrane, Pseudomonas sp., Sphingomonas sp.

\section{Introduction}

Sea water desalination is an increasing practice all over the world. Urban populations that live close to coastal areas can acquire significant quantities of fresh 
water through desalination [1]. Reverse osmosis (RO) membranes perform an effective desalination method in terms of permeability, packing density, and fouling control [1] [2] [3]. Conversely, membrane fouling reduces membrane lifetime and increases cost-effective maintenance. In particular, organic fouling could result in water flux decline through RO membranes so complex structures are formed by dissolved organic matters in combination with other substances [4] [5] [6]. Unlike inorganic fouling caused by salt precipitation, organic fouling consists of marine organisms and their metabolic residues such as extracellular polysaccharides, proteins and lipids. Bacteria cells are enclosed in self-produced extracellular polymeric substances that adhere the bacteria to osmosis membranes [7] [8] [9].

Bacteria fouling is difficult to eradicate with pre-treatment methods, which has huge implications on operational costs. Several approaches based in dissecting fouled-RO membranes have given greater understanding of the specific origin and composition of biofilms.

Bacteria analyses of $\mathrm{RO}$ membranes have identified bacteria from phyla $\beta$-proteobacteria, $\gamma$-proteobacteria and $\alpha$-proteobacteria, with representative genus of Sphingomonas, Pseudomonas and Acidovorax [10] [11]. This has allowed science to discover the types of bacteria that adhere, grow and participate in forming the biofilm on $\mathrm{RO}$ membranes. Biochemical analysis of fouled-RO membranes has also described conspicuous information on bacteria communities, although only between $0.01 \%$ and $3 \%$ of the population in natural environments has been described.

Notwithstanding the above, molecular identification based on 16s rRNA gene and the specific genes that encode both fouling and anti-fouling proteins can also reveal important information and allow for the development of biotechnological applications in the future. We hypothesised that appropriate identification of the dominant bacteria from biofouling, along with the study of gene behaviour has to improve RO-membranes designs in order to prevent biofouling. The objective of this work was to molecularly characterise bacteria associated with several kinds of RO membranes with culture-dependent and culture-independent techniques, based on region 16s rRNA.

\section{Materials and Methods}

\subsection{Bacteria Detachment Procedure}

Four reverse osmosis membranes were employed for the experiments (Hydranautics SCW4 plus, Dow Filmtec SW30HR LE-400, Nano $\mathrm{H}_{2} \mathrm{O}$ Qfx SW 365 ES and Nitto SWC4+). Each membrane was removed from the pressure vessel once it completed its design life cycle at the desalination plant located on the east coast of Gran Canaria (Canary Islands, Spain). The main characteristics of the membrane are shown in Table 1.

The removed RO membrane was taken apart and opened in the laboratory. The membrane was then laid out and cut in $12 \times 12 \mathrm{~cm}$ (approx. 8 pieces per 
Table 1. Main characteristics of reverse osmosis membranes used in this study.

\begin{tabular}{|c|c|c|c|c|c|c|}
\hline \multirow[b]{2}{*}{ Membrane Type } & \multirow[b]{2}{*}{$\begin{array}{l}\text { Permeate Flow } \\
\qquad\left(\mathrm{m}^{3} \mathrm{~d}^{-1}\right)\end{array}$} & \multirow{2}{*}{$\begin{array}{c}\text { Salt Rejection (\%) } \\
\text { Nominal } \\
\text { Minimum }\end{array}$} & \multirow[b]{2}{*}{ Configuration } & \multirow[b]{2}{*}{ Membrane Polymer } & \multirow{2}{*}{$\begin{array}{l}\text { Nominal } \\
\text { Membrane } \\
\text { Area: }\left(\mathrm{ft}^{2}\right) \\
\end{array}$} & \multirow[b]{2}{*}{ Reference } \\
\hline & & & & & & \\
\hline SCW4 plus & 24.6 & $\begin{array}{l}99.8 \\
99.7\end{array}$ & Spiral Wound & Composite & $\begin{array}{l}\text { Polyamide } \\
400\end{array}$ & $\begin{array}{c}\text { Hydranautics. Nitto } \\
\text { Group Co. Teaneck. } \\
\text { NJ (USA) }\end{array}$ \\
\hline SW30HR LE-400 & 28 & $\begin{array}{l}99.80 \\
99.95\end{array}$ & Spiral Wound & $\begin{array}{l}\text { Polyamide thin-film } \\
\text { composite }\end{array}$ & 400 & $\begin{array}{c}\text { Dow Filmtec Texas } \\
\text { (USA) }\end{array}$ \\
\hline Qfx SW 365 ES & 47 & $\begin{array}{l}99.75 \\
99.70\end{array}$ & 8-inch Spiral Wound & Thin-film composite & 365 & $\begin{array}{l}\mathrm{NanoH}_{2} \mathrm{O} \text { Inc. Los } \\
\text { Angeles, CA (USA) }\end{array}$ \\
\hline SWC4+ & 24.5 & $\begin{array}{l}99.8 \\
99.7\end{array}$ & Spiral Wound & Composite polyamide & 400 & $\begin{array}{l}\text { Nitto Group Co. } \\
\text { Teaneck, NJ (USA) }\end{array}$ \\
\hline
\end{tabular}

membrane) to identify and characterise the bacteria with a 16s rRNA-molecular marker. These pieces were identified according to the membrane manufacturer and placed into beaker flask containing sterile phosphate buffered saline (PBS, $\mathrm{pH}$ 7.5).

Bacteria adhered to pieces of RO membranes were detached using ultrasounds bath, orbital shaking and scraping when required. Ultrasound bath was carried out for $1 \mathrm{~min} \times 5$ times each, at room temperature. Then orbital shaking was performed overnight at $23^{\circ} \mathrm{C}$. The pieces of reverse osmosis membranes were always submerged in phosphate buffered saline.

Two approaches were used for analysing the bacteria, biochemical identification (culture-dependent) and molecular identification (16s rRNA gene, culture-independent). In addition, pure bacteria cultures were also confirmed through 16s rRNA identification.

\subsection{Bacteria Biochemical Identification}

De-attached bacteria aliquots $(200 \mu \mathrm{l})$ were plated in four different culture media. These were R2A Agar, seawater supplemented with agar, tryptone yeast agar prepared with seawater and marine agar. All the bacteria plates were then cultivated at $22^{\circ} \mathrm{C}$ and all media and reagents were purchased from Scharlab (Barcelona, Spain).

Bacteria colonies with similar morphologies in terms of shape and colour were isolated from each plate and grown successively to attain the pure culture separately. The pure bacteria cultures were characterised with API 20 NE (BioMerieux, Craponne, France) to identify non-fastidious and non-enteric Gram-negative rods, combining 8 conventional tests and 12 assimilation tests. API $20 \mathrm{NE}$ test were performed according to the instructions of the supplier. In addition, three independent biochemical reactions were performed: Gram staining, catalase and oxidase reagent strips (Scharlab, Barcelona, Spain).

\subsection{Bacteria Molecular Identification}

In order to characterise the bacteria molecularly, environmental DNA from de- 
tached bacteria in the PBS solution was obtained from centrifugation at 15,000 g for 15 min. DNA was also obtained from pure-colonies from bacteria colonies isolated individually in different culture media as previously described. When bacteria biomass needed to be increased, pure colonies were cultivated in sterile PBS solution containing tryptone $\left(10 \mathrm{~g} \cdot \mathrm{l}^{-1}\right)$ and yeast extract $\left(5 \mathrm{~g} \cdot \mathrm{l}^{-1}\right)$ at $23^{\circ} \mathrm{C}$ for $24 \mathrm{~h}$. The culture was then centrifuged under the experimental conditions described above (i.e. $15,000 \mathrm{~g}$ for $15 \mathrm{~min}$ ) and the resulting pellet was taken as template DNA.

DNA extraction was performed following the Murray and Thompson [12] procedure with modifications. DNA from each of the pure colonies and from detached bacteria pellets (sediments) were separately isolated. This way, the bacteria were homogenised in liquid nitrogen and then incubated in $800 \mu \mathrm{l}$ of isolation solution containing $100 \mathrm{mM}$ Tris- $\mathrm{HCl}(\mathrm{pH} 8.2), 4 \mathrm{M} \mathrm{NaCl}, 20 \mathrm{mM}$ EDTA, CTAB (2\%, w/v), PVPP $(0.1 \%, w / v)$, SDS $(0.1 \%, w / v)$ and mercaptoethanol (2\%) in a water bath at $65^{\circ} \mathrm{C}$ for $1 \mathrm{~h}$. A volume of chloroform was then added: isoamyl alcohol solution (24:1 v/v) was added and the samples were gently mixed by inversion at intervals of $20 \mathrm{~s}$. The mixture was then centrifuged for $10 \mathrm{~min}$ at $3000 \mathrm{rpm}$ in a Beckman Coulter Allegra X-22R centrifuge (Beckman Coulter Inc. Brea, CA USA). Successive washings with chloroform: isoamyl alcohol $(24: 1 \mathrm{v} / \mathrm{v})$ solution were performed. The supernatant was then placed in a fresh tube and an equal volume of n-propanol $\left(-20^{\circ} \mathrm{C}\right)$ was added, mixed gently and centrifuged at $13,000 \mathrm{~g}$ for $30 \mathrm{~min}$. The resulting pellet, containing DNA was washed with ethanol $(80 \%, \mathrm{v} / \mathrm{v}$, molecular grade), dried and suspended in sterile deionised water. DNA yield was assessed using a Nanodrop ND-1000 spectrophotometer (NanoDrop Technologies, Wilmington, Delaware, USA). All samples were in triplicate. Purity DNA was valued by smear absence migrating on a $0.8 \%(\mathrm{w} / \mathrm{v})$ agarose gel.

After several attempts with various 16s rRNA gene primer designs, DNA (90 $95 \mathrm{ng}$ ) was amplified using oligonucleotide pairs, 16s rRNA-F as a forward primer, and $16 \mathrm{~s}$ rRNA-R as a reverse primer (Table 2).

Amplification was performed in a GenAmp 2400 thermal cycler (PerkinElmer Inc., USA) with 30 cycles consisting at $95^{\circ} \mathrm{C}$ for $1 \mathrm{~min}, 55^{\circ} \mathrm{C}$ for $1 \mathrm{~min}$, and $72^{\circ} \mathrm{C}$ for $1.5 \mathrm{~min}$, followed by a final extension step of $5 \mathrm{~min}$ at $72^{\circ} \mathrm{C}$. Each PCR reaction mixture contained $0.5 \mathrm{U}$ Takara Ex Taq DNA polymerase (TaKaRa Shuzo Co., Shiga, Japan), dNTP, $2.5 \mathrm{mM}$, Takara Ex Taq PCR buffer with $\mathrm{MgCl}_{2}, 10 \mu \mathrm{l}$, forward and reverse primers, $10 \mu \mathrm{M}$ each and DNA template.

PCR products were visualised by agarose gel electrophoresis. In addition, amplification products ranging from 800 to $1200 \mathrm{bp}$ were obtained and purified using the QIAEX agarose gel extraction kit (Qiagen Inc., Hilden, Germany). The fragments were then ligated to the pGEM-T-easy cloning vector (Promega, Wisconsin, USA) and cloned in JM109 cells according to the manufacturer's instructions (Promega). Plasmids were isolated using a plasmid purification kit (Qiagen Inc.). The insert in the plasmid was checked by PCR using primers M13F and M13R (Promega). The insert was then sequenced on both strands 
Table 2. Sequences of the forward (F) and reverse (R) primers, for 16s rRNA gene. Sequences were retrieved from [13] [14].

\begin{tabular}{ccl}
\hline Gene & Primer name & \multicolumn{1}{c}{ Sequence (5'-3') } \\
\hline & Forward & TTCGGAATAACAGTTG \\
Reverse & CGGCTGGATCTAAGGA \\
& Forward & GAGTTTGATCCTGGCTCAG \\
Reverse & ACG GHT ACC TTG TTA CGA CTT \\
& Forward & AGAGTTTGATCMTGGCTCAG \\
Reverse & TACGGYTACCTTGTTACGACTT \\
& Forward & CCAGCAGCGCTAATACG \\
& Reverse & TACCAGGGTATCTAATCC \\
\hline
\end{tabular}

using an ABI-310 DNA automated sequencer (Applied Biosystems, Foster City, CA, USA) and BigDye Terminator v3.1. Nucleotide sequences were submitted to NCBI GenBank BLAST search and identified through similarity values. Alignment of 16s rRNA sequences was performed with ClustalX v.1.7 [15] using the default settings and was further refined by visual inspection. The alignment output was used to generate a phylogenetic tree based on the Maximum Likelihood method and General Time Reversibility model [16] as implemented in MEGA X [17]. The bootstrap consensus tree inferred from 1000 replicates is taken to represent the evolutionary history of the taxa analysed [18]. Branches corresponding to partitions reproduced in less than $50 \%$ of the bootstrap replicates collapse. The percentage of replicate trees in which the associated taxa clustered together in the bootstrap test (1000 replicates) are shown next to the branches [18]. Initial tree(s) for the heuristic search were obtained automatically by applying Neighbour-Join and BioNJ algorithms to a matrix of pairwise distances estimated using the Maximum Composite Likelihood (MCL) approach, and then selecting the topology with superior log likelihood value. A discrete gamma distribution was used to model evolutionary rate differences between sites $(2$ categories $(+G$, parameter $=0.1000)$ ).

\section{Results and Discussion}

The microbial community of biofouling in RO membranes is barely known since many papers are based on bacteria which are easily cultivable on a nutrient rich artificial medium. As a benchmark, this paper focuses on isolates using approaches based on culture-dependent and culture-independent techniques through the clone library. Differences between the four reverse osmosis membranes analysed were not observed.

Although bacteria were able to grow in all the culture media-namely R2A Agar, seawater supplemented with agar, tryptone yeast agar prepared with seawater, and marine agar-, R2A Agar media showed the highest recovery of bacteria colonies and was used to differentiate bacteria. Thus, six different colonies were characterised and selected in order to obtain pure culture (Table 3). 
Table 3. Pure colonies (colony number from 1 to 6) cultured on R2A Agar and distinctive morphological characteristics.

\begin{tabular}{cc}
\hline Colony number & Morphological Characteristics \\
\hline 1 & Orange \\
2 & White uniform \\
3 & White with expansive growth \\
4 & Transparent \\
5 & Beige \\
6 & Yellow \\
\hline
\end{tabular}

Biochemical tests performed with API $20 \mathrm{NE}$ are shown in Table 4. Substrate assimilations were read after 24 and $48 \mathrm{~h}$. The results were interpreted after $48 \mathrm{~h}$ using the identification software from the BioMérieux web site [19]. When required, API tests were carried out two or three times to corroborate ambiguous sugar results that were inconclusive at $42^{\circ} \mathrm{C}$. The results agreed with those previously reported in bacteria from sugar-starved habitats that were able to develop alternative metabolic pathways for sugars [20]. The API results also only showed gram-negative bacteria colonies (Table 4).

Although it was easy to grow the bacteria, the presence of gram-negative bacteria suggested that the natural bacteria communities were not fully represented. Hence, this work was also supported by culture-independent techniques. Khambhaty and Plumb [21] reported that a culture-based approach favoured the presence of bacteria such as proteobacteria over other bacteria groups. Moreover, over $99 \%$ of bacteria in seawater reverse osmosis membranes cannot be cultivated on nutrient rich artificial media [22].

Moreover, the API test allowed us to identify four out of six bacteria colonies at species level based on a $>90 \%$ confidence level reported by the manufacturer (Table 5).

As Table 5 shows, the bacteria species identified were Vibrio metschnikovii, Aeromonas salmonicida ssp. salmonicida w., Brevundimonas vesicularis and Sphingomonas paucimobilis. These biofouling bacteria were reported on the four RO membranes analysed, indicating that they probably adapted to attaching on RO membrane surfaces as they grew on different types of membranes. Although all these species were recognised as marine species, Sphingomonas $s p$. also constituted the dominant bacteria colonies. Sphingomonas has been described as the dominant bacteria on RO membranes of desalination plants and in water purification processes, as related with the formation of biofilms by this bacterium [11]. Sphingomonas also facilitates the adherence of other bacteria and encourages the maturing of the biofilm [23]. Thus, these results open the door to investigating bacteria communities involved in biofouling and their role in triggering a biofilm network.

Several Sphingomonas colonies were molecularly identified using the 16s rRNA gene. Using maximum likelihood, the analysis recovered a higher resolution 
Table 4. Biochemical test from API 20 NE (BioMerieux, Craponne, France) in six pure bacteria colonies.

\begin{tabular}{|c|c|c|c|c|c|c|}
\hline \multirow[t]{2}{*}{ API test } & \multicolumn{6}{|c|}{ Bacteria Colonies } \\
\hline & 1 & 2 & 3 & 4 & 5 & 6 \\
\hline Gram & - & - & - & - & - & - \\
\hline Catalase & - & + & + & - & + & + \\
\hline $\mathrm{NO} 3$ & - & - & + & - & - & - \\
\hline TRP & - & - & - & - & - & - \\
\hline GLU & - & - & - & - & - & - \\
\hline $\mathrm{ADH}$ & - & - & - & - & - & - \\
\hline URE & - & - & - & - & - & - \\
\hline ESC & - & - & + & + & - & + \\
\hline GEL & + & - & + & + & + & - \\
\hline PNPG & + & - & - & - & - & + \\
\hline GLU & + & + & + & - & + & + \\
\hline ARA & - & - & - & - & - & - \\
\hline MNE & - & - & - & - & - & - \\
\hline MAN & + & - & - & - & + & - \\
\hline NAG & + & + & + & + & + & - \\
\hline MAL & + & + & + & + & + & + \\
\hline GNT & + & + & + & - & + & - \\
\hline CAP & - & - & - & - & - & - \\
\hline $\mathrm{ADI}$ & - & - & - & - & - & - \\
\hline MLT & - & - & + & - & - & + \\
\hline CIT & - & - & - & - & - & - \\
\hline PAC & - & - & - & - & - & - \\
\hline Oxidase & - & + & + & + & + & + \\
\hline
\end{tabular}

Table 5. Taxonomical identification, profile and confidence level, according to API 20 $\mathrm{NE}$, corresponding to 6 pure colonies.

\begin{tabular}{cccc}
\hline $\begin{array}{c}\text { Colony } \\
\text { number }\end{array}$ & Genus and Specie assignation & Profile & Confidence level \% \\
\hline 1 & Vibrio metschnikovii & Very good & 99.9 \\
2 & - & Low discrimination & - \\
3 & Aeromonas salmonicida ssp salmonicida & Good & 97.6 \\
4 & Brevundimonas vesicularis & Acceptable & 86.5 \\
5 & - & Unacceptable & - \\
6 & Sphingomonas paucimobilis & Good & 96.5 \\
\hline
\end{tabular}


Table 6. Sequences of 16s rRNA-gene sequences corresponding to diverse Sphingomonas strains.

\begin{tabular}{|c|c|}
\hline Species and strain & Accession No. \\
\hline \multicolumn{2}{|l|}{ Proteobacteria phylum } \\
\hline \multicolumn{2}{|l|}{$\alpha$-Proteobacteria } \\
\hline \multicolumn{2}{|l|}{ Sphingomonadaceae family, Sphingomonas genus } \\
\hline Sphingomonas abaci $\mathrm{C} 42$ & AJ575817 \\
\hline Sphingomonas abaci $\mathrm{C} 42$ & NR_042192 \\
\hline Sphingomonas abaci SS1-08 & KU341393 \\
\hline Sphingomonas adhaesiva IFO 15099 & NR_043391 \\
\hline Sphingomonas adhaesiva BPM19 & MF289214 \\
\hline Sphingomonas aerolata R-36940 & FR691420 \\
\hline Sphingomonas aerolata $1111 \mathrm{TES} 25 \mathrm{Y} 1$ & LN774415 \\
\hline Sphingomonas aquatilis MPR 1 & KX110354 \\
\hline Sphingomonas aquatilis $\mathrm{S} 7$ & KF542913 \\
\hline Sphingomonas asaccharolytica IFO 15499-T & Y09639 \\
\hline Sphingomonas asaccharolytica Gsoil 130 & KY078832 \\
\hline Sphingomonas aurantiaca MA101b & AJ429236 \\
\hline Sphingomonas aurantiaca MA306a & AJ429237 \\
\hline Sphingomonas azotifigens NBRC 15497 & AB217471 \\
\hline Sphingomonas azotifigens NBRC 15497 & AB680881 \\
\hline Sphingomonas desiccabilis $\mathrm{CP} 1 \mathrm{D}$ & NR_042372 \\
\hline Sphingomonas desiccabilis $\mathrm{CP} 1 \mathrm{DT}$ & AJ871435 \\
\hline Sphingomonas echinoides S32312 & AB649019 \\
\hline Sphingomonas echinoides NRRL B-3126 & MG745876 \\
\hline Sphingomonas dokdonensis DS-4 & NR_043612 \\
\hline Sphingomonas dokdonensis DS-4 & DQ178975 \\
\hline Sphingomonas mali $\mathrm{S} 32423$ & AB649020 \\
\hline Sphingomonas mali GM289 & AB740933 \\
\hline Sphingomonas molluscorum An 18 ( KMM 3882) & AB248285 \\
\hline Sphingomonas molluscorum EP2 & MG778708 \\
\hline Sphingomonas panni $\mathrm{T} 9 \mathrm{BP} 11$ & JF459953 \\
\hline Sphingomonas panni L8-752 & JQ659481 \\
\hline Sphingomonas panni $\mathrm{T} 9 \mathrm{BR} 13$ & JF459952 \\
\hline Sphingomonas parapaucimobilis JCM 7510 & NR_115615 \\
\hline Sphingomonas parapaucimobilis JCM 7510T & D84525 \\
\hline Sphingomonas paucimobilis BN 2056 & MG438514 \\
\hline Sphingomonas paucimobilis MFC-pH7 01 & KY434108 \\
\hline Sphingomonas pituitosa NBRC 102491 & NR_114119 \\
\hline Sphingomonas pituitosa EDIV & AJ243751 \\
\hline Sphingomonas pruni NBRC 15498 & NR_113760 \\
\hline Sphingomonas pruni IFO 15498 & NR_026373 \\
\hline Sphingomonas soli $\mathrm{T} 5-04$ & AB166883 \\
\hline Sphingomonas soli NBRC 100801 & $\mathrm{AB} 681244$ \\
\hline Sphingomonas wittichii $\mathrm{RW} 1$ & NR_027525 \\
\hline Sphingomonas wittichii $\mathrm{HJX} 9$ & KР979540 \\
\hline Sphingomonas sp. MAH-20 & MH368767 \\
\hline \multicolumn{2}{|l|}{ Other Sphingomonadaceae genera } \\
\hline Blastomonas aquatica PE 4-5 & KJ528316 \\
\hline
\end{tabular}




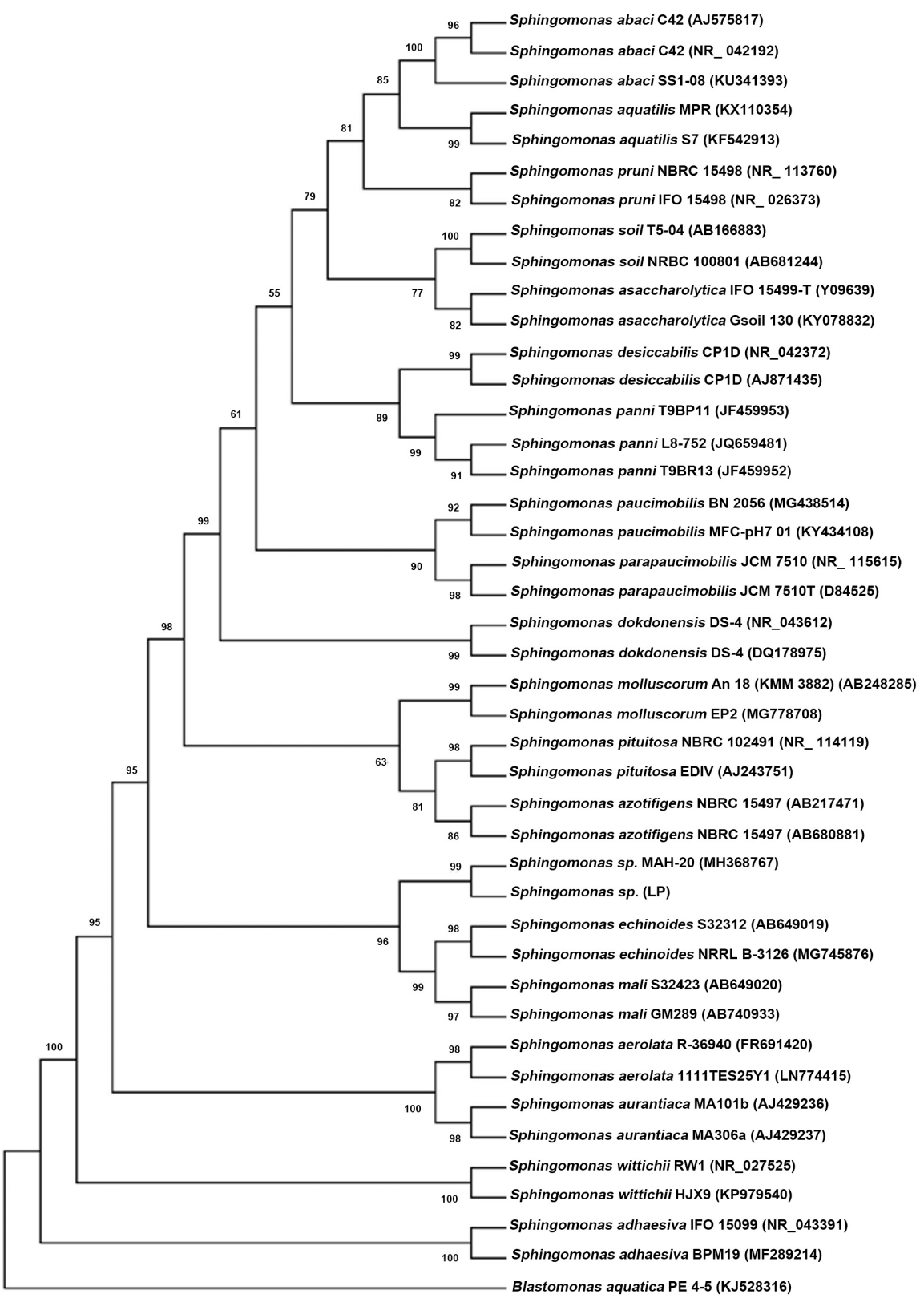

Figure 1. Maximum likelihood (ML) tree of Sphingomonas sp. inferred from 16s rRNA sequence calculated using general time reversible model plus gamma distribution (2 categories $(+G$, parameter $=0.0500)$ ). Number in node represents values referring to sequence similarity. Bootstrap test was performed with 1000 replicates. LP in brackets indicates sequences analysed in the present study.

and grouped 16s rRNA Sphingomonas with another $4316 \mathrm{~s}$ rRNA gene sequences annotated as belonging to this genus (Table 6).

There were a total of 1023 positions in the final dataset. The phylogenetic analysis positioned the Sphingomonas sequences, from colonies determined biochemically, within the Shingomonas $s p$. genus. This result (Figure 1) demonstrated that the Sphingomonas obtained in this study could be regarded as representing a species within the genus. 
Table 7. Sequences of 16s rRNA-gene sequences corresponding to diverse Pseudomonas strains.

\begin{tabular}{|c|c|}
\hline Species and strain & Accession No. \\
\hline \multicolumn{2}{|l|}{ Proteobacteria phylum } \\
\hline \multicolumn{2}{|l|}{$\gamma$-Proteobacteria } \\
\hline \multicolumn{2}{|l|}{ Pseudomonadaceae family, Pseudomonas genus } \\
\hline Pseudomonas aeruginosa $\mathrm{H} 8$ & MG706125 \\
\hline Pseudomonas aeruginosa $\mathrm{ACa} 02$ & KJ754135 \\
\hline Pseudomonas aeruginosa $\mathrm{B} 2$ & KC633284 \\
\hline Pseudomonas argentinensis MSS- 10 & KM280652 \\
\hline Pseudomonas argentinensis AL243 & MG819449 \\
\hline Pseudomonas argentinensis $\mathrm{FPBBIH7}$ & KU605764 \\
\hline Pseudomonas cuatrocienegasensis SR7-86 & LN995508 \\
\hline Pseudomonas cuatrocienegasensis SR7-79 & LN995501 \\
\hline Pseudomonas indica MBK3 & MF682348 \\
\hline Pseudomonas indica VITPADJ5 & KU598847 \\
\hline Pseudomonas indica NRCNA & MH917935 \\
\hline Pseudomonas indica NBRC & NR_114196 \\
\hline Pseudomonas marincola KMM 3042 & NR_041592 \\
\hline Pseudomonas marincola K-W14 & JQ799067 \\
\hline Pseudomonas nitroreducens $\mathrm{R} 5-791$ & JQ659791 \\
\hline Pseudomonas nitroreducens $\mathrm{R} 5-760-1$ & JQ659788 \\
\hline Pseudomonas nitroreducens $\mathrm{R} 5-758-1$ & JQ659785 \\
\hline Pseudomonas nitroreducens $\mathrm{R} 1-348$ & JQ659567 \\
\hline Pseudomonas synxantha X3-5-1 & MK120107 \\
\hline Pseudomonas synxantha KGGI14 & MH079449 \\
\hline Pseudomonas synxantha UCM B-399 & MF196188 \\
\hline Pseudomonas synxantha IAM 12356 & NR_043425 \\
\hline \multicolumn{2}{|l|}{ Other Pseudomonadaceae genera } \\
\hline Azomonas agilis NBRC 102607 & NR_114164 \\
\hline
\end{tabular}

On the other hand, sequencing of 16s rRNA gene amplification fragments, assumed as operational taxonomic units (OTU) from independent cultures, revealed forty $16 \mathrm{~s}$ rRNA gene fragments which were identified. Thirty percent of the total number of amplification fragments (total number of OTU, 40) was related to Pseudomonas species and 3 OTUs to Sphingomonas. The dominance of Pseudomonas may be explained by the association of these organisms with submerged surfaces. The remaining sequences were unrelated to other known bacteria and these were identified as non-representative. A total of 25 OTUs were detected as possible chimeras and were excluded from analysis.

Evolutionary analysis using the Maximum Likelihood method involved 24 nucleotide sequences (Table 7) with a total of 687 positions in the final dataset. 


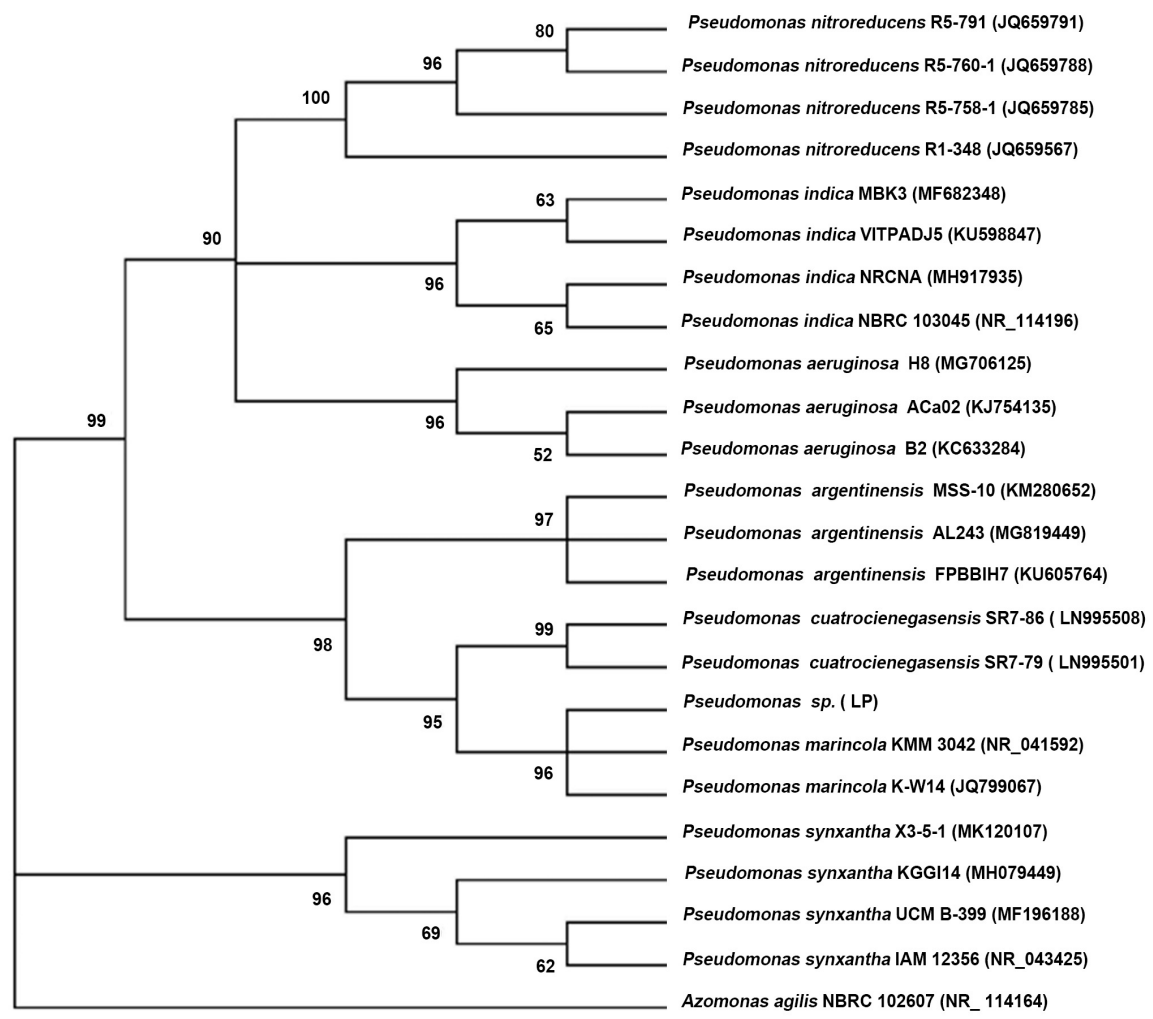

Figure 2. Maximum likelihood (ML) tree of Pseudomonas $s p$. inferred from 16s rRNA sequence calculated using general time reversible model plus gamma distribution (2 categories $(+\mathrm{G}$, parameter $=0.1000)$ ). Number in node represents values referring to sequence similarity. Bootstrap test was performed with 1000 replicates. LP in brackets indicates sequences analysed in the present study.

The phylogenetic analysis positioned the Pseudomonas sequences in a clade within Pseudomonas marincola (Figure 2). Pseudomonas marincola has been recently annotated as a marine species [22].

All in all, assuming the criterion for differentiating bacteria with a 16s rRNA gene sequence similarity value of over 95\% [24], the phylogenetic trees of Sphingomonas sp. and Pseudomonas marincola were consistent with the molecular characterisation and their affiliations to the respective genus.

From an application point of view, it is worth mentioning that Sphingomonas and Pseudomonas have been described as containing an open reading frame coding for enzymes that are necessary for the initial stages of biofilm development [13]. Therefore, these molecular identifications open the door to studying the gene expression levels that encode the attachment protein and the biofouling potential of these bacteria. Gene expression levels of fouling and antifouling proteins under different experimental conditions (i.e. high-pressure water, permeate flow) can help to: 1) indicate a functional inclination to form biofilm on a reverse osmosis membrane, 2) discover how the membrane surface is colonised, and 3) determine how extracellular polysaccharides can help to initiate biofilm formation. 


\section{Conclusion}

In conclusion, Sphingomonas sp. and Pseudomonas sp. assigned as P. marincola, have been identified on fouled marine reverse osmosis membranes. Culture-dependent and culture-independent approaches (clone library) showed that although the bacteria communities were not all identical, two dominant bacteria were commonly observed on the four RO membranes analysed.

\section{Author's Contributions}

P.G.J. conceived, designed and wrote the manuscript. M.C.A. conducted the phylogeny analysis. C.E.P and I.L.A. carried out microbiological assays. J.A.H.M. and J.R.B.R. analysed microbiological data. All the authors read and approved the manuscript.

\section{Funding}

This research was supported by the collaboration of Ministerio de Ciencia, Innovación y Universidades and from the Universidad de Las Palmas de Gran Canaria. (Grant CGL2016-78442-C2-2-R, GOBESP2017-04 ULPGC) to PGJ, and co-funded by ERDF funds, INTERREG MAC 2014-2020 programme, within the DESAL+ project (MAC/1.1a/094)". M.C.A was supported by a predoctoral fellowship granted by the University of Las Palmas de Gran Canaria (ULPGC2016).

\section{Conflicts of Interest}

The authors declare no conflict of interest.

\section{References}

[1] Fritzmann, C., Löwenberg, J., Wintgens, T. and Melin, T. (2007) State-of-the-Art of Reverse Osmosis Desalination. Desalination, 216, 1-76. https://doi.org/10.1016/j.desal.2006.12.009

[2] Rautenbach, R. and Melin, T. (2003) Mebranverfahren: Grundlagen der Modul-und Anlagenauslegung. 2nd Edition, Springer-Verlag, Berlin.

[3] Belila, A., El-Chakhtoura, J., Otaibi, N., Muyzer, G., Gonzalez-Gil, G., Saikaly, P.E., van Loosdrecht, M.C.M. and Vrouwenvelder, J.S. (2016) Bacterial Community Structure and Variation in a Full-Scale Seawater Desalination Plant for Drinking Water Production. Water Research, 94, 62-72. https://doi.org/10.1016/j.watres.2016.02.039

[4] Naidu, G., Jeong, S., Kim, S.J., Kim, I.S. and Vigneswaran, S. (2014) Organic Fouling Behavior in Direct Contact Membrane Distillation. Desalination, 347, 230-239. https://doi.org/10.1016/j.desal.2014.05.045

[5] Shen, J. and Schafer, A.I. (2015) Factors Affecting Fluoride and Natural Organic Matter (NOM) Removal from Natural Waters in Tanzania by Nanofiltration/Reverse Osmosis. Science of the Total Environment, 527-528, 520-529. https://doi.org/10.1016/j.scitotenv.2015.04.037

[6] Ding, S., Yang, Y., Li, C., Huang, H. and Hou, L.A. (2016) The Effects of Organic Fouling on the Removal of Radionuclides by Reverse Osmosis Membranes. Water Research, 95, 174-184. https://doi.org/10.1016/j.watres.2016.03.028 
[7] Frølund, B., Palmgren, R., Keiding, K. and Nielsen, P.H. (1996) Extraction of Extracellular Polymers from Activated Sludge Using a Cation Exchange Resin. Water Research, 30, 1749-1758. https://doi.org/10.1016/0043-1354(95)00323-1

[8] Liu, H. and Fang, H.H. (2002) Extraction of Extracellular Polymeric Substances (EPS) of Sludges. Dournal of Biotechnology, 95, 249-256.

https://doi.org/10.1016/S0168-1656(02)00025-1

[9] Subbiahdoss, G., Zeng, G., Aslan, H., Ege Friis, J., Iruthayaraj, J., Zelikin, A.N. and Meyer, R.L. (2019) Antifouling Properties of Layer by Layer DNA Coatings. Biofouling, 35, 75-88. https://doi.org/10.1080/08927014.2019.1568417

[10] Ivnitsky, H., Katz, I., Minz, D., Volvovic, G., Shimoni, E., Kesselman, E. and Dosoretz, C.G. (2007) Bacterial Community Composition and Structure of Biofilms Developing on Nanofiltration Membranes Applied to Wastewater Treatment. Water Research, 41, 3924-3935. https://doi.org/10.1016/j.watres.2007.05.021

[11] Bereschenko, L.A., Heilig, G.H.J., Nederlof, M.M., van Loosdrecht, M.C.M., Stams, A.J.M. and Euverink, G.J.W. (2008) Molecular Characterization of the Bacterial Communities in the Different Compartments of a Full-Scale Reverse-Osmosis Water Purification Plant. Applied and Environmental Microbiology, 74, 5297-5304. https://doi.org/10.1128/AEM.00387-08

[12] Murray, M.G. and Thompson, W.F. (1980) Rapid Isolation of High Molecular Weight Plant DNA. Nucleic Acids Research, 8, 4321-4325. https://doi.org/10.1093/nar/8.19.4321

[13] Lee, J., Ren, X., Yu, H.W., Kim, S.J. and Kim, I.S. (2010) Membrane Biofouling of Seawater Reverse Osmosis Initiated by Sporogenic Bacillus Strain. Environmental Engineering Research, 15, 141-147. https://doi.org/10.4491/eer.2010.15.3.141

[14] Bernbom, N., Ng, Y.Y., Kjelleberg, S., Harder, T. and Gram, L. (2011) Marine Bacteria from Danish Coastal Waters Show Antifouling Activity against the Marine Fouling Bacterium Pseudoalteromonas sp. Strain S91 and Zoospores of the Green Alga Ulva australis Independent of Bacteriocidal Activity. Applied and Environmental Microbiology, 77, 8557-8567. https://doi.org/10.1128/AEM.06038-11

[15] Thompson, J.D., Higgins, D.G. and Gibson, T.J. (1994) CLUSTAL W: Improving the Sensitivity of Progressive Multiple Sequence Alignment through Sequence Weighting, Position-Specific Gap Penalties and Weight Matrix Choice. Nucleic Acids Research, 22, 4673-4680. https://doi.org/10.1093/nar/22.22.4673

[16] Nei, M. and Kumar, S. (2000) Molecular Evolution and Phylogenetics. Oxford University Press, New York.

[17] Kumar, S., Stecher, G., Li, M., Knyaz, C. and Tamura, K. (2018) MEGA X: Molecular Evolutionary Genetics Analysis across Computing Platforms. やMolecular Biology and Evolution, 35, 1547-1549. https://doi.org/10.1093/molbev/msy096

[18] Felsenstein, J. (1985) Confidence Limits on Phylogenies: An Approach Using the Bootstrap. Evolution, 39, 783-791. https://doi.org/10.1111/j.1558-5646.1985.tb00420.x

[19] Api Web, BioMérieux, Marcy-l’Étoile, France. https://apiweb.biomerieux.com

[20] Bräsen, C., Esser, D., Rauch, B. and Siebers, B. (2014) Carbohydrate Metabolism in Archaea: Current Insights into Unusual Enzymes and Pathways and Their Regulation. Microbiology and Molecular Biology Reviews, 78, 89-175. https://doi.org/10.1128/MMBR.00041-13

[21] Khambhaty, Y. and Plumb, J. (2011) Characterization of Bacterial Population Associated with a Brackish Water Desalination Membrane. Desalination, 269, 35-40. 
https://doi.org/10.1016/j.desal.2010.10.039

[22] Ferguson, R.L., Buckley, E.N. and Palumbo, A.V. (1984) Response of Marine Bacterioplankton to Differential Filtration and Confinement. Applied and Environmental Microbiology, 47, 49-55.

[23] Pollock, T.J. and Armentrout, R.W. (1999) Planktonic/Sessile Dimorphism of Polysaccharide-Encapsulated Sphingomonads. Journal of Industrial Microbiology \& Biotechnology, 23, 436-441. https://doi.org/10.1038/sj.jim.2900710

[24] Stackebrandt, E. and Goebel, B.M. (1994) Taxonomic Note: A Place for DNA-DNA Reassociation and 16s rRNA Sequence Analysis in the Present Species Definition in Bacteriology. International Journal of Systematic Bacteriology, 44, 846-849.

https://doi.org/10.1099/00207713-44-4-846 